\title{
Influence of Home Environment on Adolescent Psychological Well-being
}

\author{
Jeny Rapheal*, Deepa. K Damodaran**, Varghese Paul. K***
}

\section{ABSTRACT:}

To analyze the pattern in which home environment affected various aspects of psychological well-being of adolescents, 153 higher secondary school students were selected randomly from five schools of Kerala state. Data collected using psychological well-being scale and home environment inventory, on analysis, revealed significant correlations between the subscales of both measurements. As per multiple regressions, negative HE mainly affected the "interpersonalrelation" and "sociability" levels of adolescents. Disciplinary variables showed significant predictive power in "satisfaction", "sociability", and "interpersonal relationship" aspects of psychological well-being. Meanwhile, Positive HE variables exhibited significant predictive power in all the five aspects of psychological well-being. Demographic variables hadn't any significant effect on psychological well-being. Counselors, parents, teachers and other caretakers will be benefitted from these revelations about the subtle environmental pathways into the psychological well-being of adolescents.

Keywords: Adjustment, married, unmarried, industry

\section{INTRODUCTION}

Ecological perspectives indented to delineate subtle pathways into the psychological well-being of individuals are gathering much significance in the new millennium. And this is particularly true for a transitional phase of development like adolescence. In the globalized world where there is rapid depletion of culturally established norms and standards of living, adolescent population is becoming more vulnerable to the complexities of their social environment as identity crisis often threatens to destabilize their mental equilibrium. This often deprives the care takers of new generation, of a firm enduring platform to judge what constituted an optimal environment for the psychological well-being of adolescents. Moreover, latest research finings keep on ratifying the view that, psychological ailments of teenagers have conspicuous etiological route in the quality of environment within which they strive to accomplish their developmental goals.

\footnotetext{
*Research Scholar in Psychology, Bharathiar University, Coimbatore

** Research Scholar in Psychology, Bharathiar University, Coimbatore

***HOD, Department of Psychology, Prajyoti Nikethan College, Pudukkad Kerala
} 
New revelations in positive psychology necessitated a reorientation in the definition of mental health as "a state of well-being in which the individual realizes his or her own abilities, can cope with the normal stresses of life, can work productively and fruitfully, and is able to make a contribution to his or her community" (WHO, 2001). Also, a growing number of longitudinal studies confirm the power of psychological well-being scales to predict outcomes, like, longevity, physical health, quality of life, criminality, drug and alcohol use, employment, earnings and pro-social behavior (WHO report, Freidli 2009, p.2). In the backdrop of these observations, ensuring psychological well-being of adolescents is a socio-psychological necessity. For adolescents, psychological well-being means being satisfied with life and experiencing a plentitude of positive emotions, when coupled with the absence of psychopathology, is associated with maximum academic function, social competency and support and physical health (Jessica \& Savage, 2011). From a broad perspective, the measurement and promotion of adolescent well-being is a desirable social and political objective. (Diener, Lucas, Schimmack \& Helliwell, 2009; Vazquez, 2009).

On amassing theoretical expoundations dealing with the mechanism that operates behind the reciprocal influence of Home Environment(HE) on Psychological Well-Being(PW), one stumbles upon ecological approach by Bronfenbrenner \& Morris (1998) which focuses on understanding interactions among developing persons, the contexts of development, and the processes that account for development. Family systems theory (Minuchin 2002) has led to a greater awareness of the relationships and mutual influences among different subsystems in the family. In particular, family, religion, and ethnicity have been identified as important sources of well-being (Motkal Abu-Rayya, 2006; Lim \& Putnam, 2010). Bowlby's (1988) attachment theory stresses on experiences with caregivers, which is likely to shape people's working models of the world, exerting a continuing influence on development, including individual differences in life satisfaction. Well-being within the group context was studied by optimal distinctiveness theory (ODT; Brewer, 1991, 1993). The basis of this theory was social identity theory (Tajfel \& Turner, 1986) and self-categorization theory (Turner, Hogg, Oakes, Reicher, \& Wetherall, 1987) which deals with the formation of self concept from group membership. Social cognitive theory by Bandura, (1986, 1997, 2001) views individuals as products and producers of their own environments. Salient among these theories is Social determination theory which views wellbeing as a consequence of optimal psychological functioning resulting from the adequate satisfaction of psychological needs namely autonomy, competence and relatedness and a system of congruent and coherent goals (Dec i\& Ryan, 2000). These basic psychological needs coincides with three of the dimensions in Ryff's model of psychological well-being (Lent,2003). And meeting a psychological need verily engender positive outcomes(Baumeister \& Leary, 1995) providing "deep inner sense of wellness, vitality and psychological flexibility" (Ryan \& al., 1995) This theory attempts to give an account of the motivational processes by which individuals seek autonomy and self-expression within the context of social relationships. 
Present study explored psychological well-being of the selected sample along five dimensions namely, life-satisfaction, efficiency, interpersonal relations, sociability and mental health. There is ample proof in the literature that each of these aspects of psychological well-being is affected by the environment, especially the home environment of adolescents saturated with parenting style. Life satisfaction a judgmental process, in which individuals assess the quality of a person's life based on selected standards (Pavot \& Diener, 1993) is influenced by differences in family structure (Demo \&Acock, 1996; Zullig, Valois, Huebner, \&Drane, 2005) and parenting behavior (Petito\& Cummins, 2000; Suldo\& Huebner, 2004b).Family relations have the highest correlation with life satisfaction in compared to peers, school and life environment (Suldo \& Huebner, 2006).

Interpersonal relation is another major aspect of psychological well-being. According to Sine (1998) students who benefited from authoritative parenting style exhibit a higher degree of warmth, are able to regulate their emotions, develop trust in others as well as themselves than those grew up in authoritarian and permissive back ground. Albers et al. (2004) finds that disturbed family functioning predicted poor quality of later intimate relationships and family relationships have been found to be important for the quality of peer relationship (Kerns, Klepac \& Cole, 1996). According to attachment theory, there exists a causal relationship between formative experiences with parents and one's ability to form and maintain later positive relationships with others (Bowlby, 1989).

"Efficiency" component of psychological well-being, which is defined as "the comparison of what is actually produced or performed with what can be achieved" can be interpreted from the academic development of an adolescent life. This area also, is significantly affected by family environment and much of the previous results clustered around parenting.Parental involvement via an authoritative home environment promote adolescent school success (Steinberg et al. 1992). Sarada Devi and Kavita Kiran (2002) found that there was close association between family factors and scholastic backwardness. Latha (2005) observed that family environment appeared to influence home adjustment as well as academic performance. In general, stressors in the environment may affect students' cognitive processes, such as concentration and memory (Fisher, 1994) and thus affect their "efficiency".

"Sociability", an indicator to estimate the positive affect related to social life of adolescents ,defined as the "preference for being in the company of others versus being alone" (Cheek \& Buss, 1981) is also affected by socializing methods and practices adopted by the family. Increased parent-adolescent communication, and improved the quality of relationships have been shown to be effective and consequently positively influence adolescent social development (Hair, Jager, \& Garrett, 2001). There does exist inter-relationships between home environment and social intelligence (Kaur \& Kalaramna 2004). Children from favorable environment homes 
are found to be warmhearted, outgoing and socially more intelligent than children from unfavorable homes (Rani 1998).

Coming to the "mental health", researches prove that less than half of the risk factors for developing mental health disorders are genetic (More et al., 2013), suggesting that the majority of influence on teenage mental health is learned, or environmental. OConnell et al (2009) lists environmental risk factors for mental illness for teenagers such as disrupted home life, parental strife or divorce, parent mental illness, abuse, and social problems at school. Meanwhile, Close parent/adolescent relationships, good parenting skills, shared family activities and positive parent role modeling all have positive effect on adolescent health and development(Hair, Moore, Garrett, Kinukawa, Lippman, \& Michelson, 2005; Parker, \& Benson, 2004; Resnick, Ireland, \& Borowsky, 2004)). Thus mental health is something inextricably embedded in the dynamics of environment.

The present study in addition to estimating the environmental factors that have significant role in the overall of psychological well-being of adolescent group, probe into the pattern of influence of Home Environment on the psychological well-being. How home environmental variables differentiate themselves in contributing to various indicators of psychological well-being was our concern. Such an analysis we hope, will contribute mainly to the field of psychotherapy and counseling of adolescents suffering from various psychological aberrations. Awareness about the far reaching consequences of various disciplinary, socializing practices adopted by adults in the psychological well-being of adolescents presents the therapists, counselors, parents and other care takers with a new frame of reference in diagnosis and appropriate selection of intervention strategies. With this aim in mind we were interested in following objectives.

1) What factors of psychological environment of home contributed to the overall psychological well-being of adolescents?.

2) Which home environment variables were significant in each component of psychological well-being of adolescents namely life satisfaction, sociability, interpersonal relations, mental health and efficiency of adolescents?

3) Which aspects of the psychological wellbeing of adolescents were mainly affected by the disciplinary HE variables namely "control", "conformity" and "protectiveness"?

4) Which aspects of the psychological wellbeing of adolescents were mainly affected by a negative home environment?

5) Which aspects of the psychological wellbeing of adolescents were mainly affected by a positive home environment? 


\section{METHOD}

\section{Participants}

Sample consisted of 153 adolescents selected from two private ( $\mathrm{N}=51)$, two aided $(\mathrm{N}=64)$, one government $(\mathrm{N}=38)$ schools of THRISSUR district in Kerala state. There were 86 boys and 67 girls. Mean age of participants was 15.84 .

\section{Instruments}

1. Home Environment Inventory (HEI): Developed by Karuna Shankar Mishra. It consists of 10 subscales namely, A-Control, B-Protectiveness, C- Punishment, D-Conformity, E-Social Isolation, F-Reward, G-Deprivation of privileges, H-Nurturance, I-Rejection and JPermissiveness. It is a 5 point Likert scale and each subscale contains 10 questions mainly intended to measure the psycho-social climate of home as perceived by children . HEI claims high content as well as criterion related validity. Established reliability coefficients of dimensions are A-.879, B-.748, C-.947, D-.866, E-.870, F-875, G-.855, H-.901, I-.841, J-.726 respectively.

2. Psychological Well-Being Scale: Developed by Devendra Sing Sisodia was used to estimate Psychological well-being of students. It is a 5 point Likert scale which estimates psychological well-being along five dimensions namely, Satisfaction, Efficiency, Sociability, Mental Health and Interpersonal relationship. The response categories were "strongly agree", "agree", "not sure", "Disagree" and "strongly disagree" respectively. Its test-retest reliability is .87 and internal consistency is .90 . Besides face validity scale claims high content validity. Validity coefficient against external criteria is .94. It consists of 50 items. 10 items for each subscale.

\section{Procedure}

Informed consent was obtained from students, parents and school authorities. After giving a brief introduction about the purpose of study, Psychological well-being scale by Devendra sing Sisodia and Home environment Inventory by Karuna Shankar Mishra were directly distributed to the students. Students were given a brief explanation on nature of responding and their queries were clarified at each step.

\section{RESULTS}

All Home Environment variables showed significant association with almost all aspects of psychological well-being. Demographic variables like age, type of school, place of residence, religion and birth order hadn't any role in the psychological well-being or its components (table:2, table:3). Multiple regression exhibited significant predictive power of disciplinary variables namely control, conformity and protectiveness in satisfaction, sociability and interpersonal relation aspects of PW (table:4). Negative home environment had adverse effect mainly on sociability and interpersonal relations. But positive home environment variables 
showed significant enhancing effect on all the five aspects of psychological well-being. Of these, influence of "nurture" and "reward" was remarkably significant.

Table:1 Correlation Results

\begin{tabular}{|c|c|c|c|c|c|c|c|c|c|c|}
\hline & A & B & $\mathrm{C}$ & D & $E$ & $\mathrm{~F}$ & $\mathrm{G}$ & $\mathrm{H}$ & I & $\mathrm{J}$ \\
\hline $\begin{array}{l}\text { Satisfactio } \\
n\end{array}$ & $\begin{array}{l}.15 \\
*\end{array}$ & $.25 * * *$ & $.14^{*}$ & .07 & -.04 & $.21 * *$ & -.01 & $.21 * *$ & -.11 & .01 \\
\hline Efficiency & .09 & .04 & .08 & $.19 * *$ & -.05 & $\begin{array}{l}.41 * * * \\
*\end{array}$ & .07 & $.27 * * *$ & -.02 & $\begin{array}{l}.18 * \\
*\end{array}$ \\
\hline Sociability & $\begin{array}{l}.14 \\
*\end{array}$ & $\begin{array}{l}.32 * * * \\
*\end{array}$ & $.21 *$ & $\begin{array}{l}.31 * * * \\
*\end{array}$ & .03 & $\begin{array}{l}.43 * * * \\
*\end{array}$ & -.01 & $\begin{array}{l}.34 * * * \\
*\end{array}$ & .02 & .01 \\
\hline M Health & $\begin{array}{l}.15 \\
*\end{array}$ & .02 & .07 & .09 & -.01 & $.23 * *$ & .01 & $.17 *$ & -.11 & .004 \\
\hline In Relation & $\begin{array}{l}.13 \\
*\end{array}$ & .23 & .05 & $.13 *$ & $\begin{array}{l}- \\
.18^{*} \\
*\end{array}$ & $\begin{array}{l}.49 * * * \\
*\end{array}$ & $\begin{array}{l}- \\
.13 \\
*\end{array}$ & $\begin{array}{l}.48 * * * \\
*\end{array}$ & $\begin{array}{l}- \\
.21 * \\
*\end{array}$ & -.07 \\
\hline PW & $\begin{array}{l}.17 \\
*\end{array}$ & $.23 * *$ & .11 & $.24 * *$ & -.09 & $\begin{array}{l}.49 * * * \\
*\end{array}$ & -.02 & $\begin{array}{l}.42 * * * \\
*\end{array}$ & -.12 & .06 \\
\hline
\end{tabular}

A-control, B-protectiveness, C-punishment, D-conformity, E-isolation, F-reward, G-deprivation of privileges, H-nurturance, I-rejection, J-permissiveness, PW-psychological well-being.

$* \mathrm{P}<.05, * * \mathrm{P}<.01, * * * \mathrm{P}<.001, * * * * \mathrm{P}<.0001$

Table:2 ANOVA Summary for PW

\begin{tabular}{|c|c|c|c|c|c|c|c|c|c|}
\hline $\begin{array}{l}\text { Independent } \\
\text { variables }\end{array}$ & $\begin{array}{l}\text { Mean } \\
(\mathrm{PW})\end{array}$ & Df & $\mathrm{F}$ & $\mathrm{P}$ & $\begin{array}{l}\text { Independent } \\
\text { variables }\end{array}$ & $\begin{array}{l}\text { Mean } \\
(\mathrm{PW})\end{array}$ & $\mathrm{SD}$ & Df & $\mathrm{T}$ \\
\hline \multirow{3}{*}{$\begin{array}{l}\text { Christian } \\
\text { Hindu } \\
\text { Muslim }\end{array}$} & 189.59 & $\begin{array}{l}2 \\
(150)\end{array}$ & .3800 & .685 & \multirow[t]{2}{*}{$\begin{array}{l}\text { Boys } \\
\text { Girls }\end{array}$} & 188.77 & 18.13 & 151 & .65 \\
\hline & 190.64 & & & & & 190.71 & 18.43 & & \\
\hline & 186.83 & & & & \multirow{2}{*}{$\begin{array}{l}\text { Rural } \\
\text { Urban }\end{array}$} & 189.75 & 16.74 & 151 & .109 \\
\hline \multirow{3}{*}{$\begin{array}{l}\text { Aided } \\
\text { Govt } \\
\text { Private }\end{array}$} & 189 & $\begin{array}{l}2( \\
150)\end{array}$ & .0616 & .9402 & & 189.43 & 20.06 & & \\
\hline & 190.16 & & & & \multirow{2}{*}{$\begin{array}{l}* \mathrm{~W}-\text { Mother } \\
* * \mathrm{H}- \\
\text { Mother }\end{array}$} & 190.88 & 17.61 & 151 & .441 \\
\hline & 189.96 & & & & & 189.27 & 18.44 & & \\
\hline \multirow{3}{*}{$\begin{array}{l}\text { Eldest } \\
\text { In-between } \\
\text { Youngest }\end{array}$} & 188.64 & $2(150)$ & .5797 & .561 & \multirow{2}{*}{$\begin{array}{l}\text { Single } \\
\text { Not-single }\end{array}$} & 189.42 & 18.11 & 151 & .3850 \\
\hline & 186.71 & & & & & 191.33 & 19.83 & & \\
\hline & 191.38 & & & & \multicolumn{5}{|c|}{$*$ Working $* *$ House wife } \\
\hline
\end{tabular}


Table:4 Multiple Regression Summary

\begin{tabular}{|c|c|c|c|c|c|}
\hline $\begin{array}{l}\text { Dependent } \\
\text { Variable }\end{array}$ & & $\mathrm{R}^{2}$ & Df & $\mathrm{F}$ & Beta loadings \\
\hline \multirow[t]{5}{*}{$\begin{array}{l}\text { Group1 } \\
\text { A,B,D }\end{array}$} & Satisfaction & .068 & $3(149)$ & $3.625 * *$ & $\mathrm{~A}=.04, \quad \mathrm{~B}=.24 * *, \quad \mathrm{D}=-.02$ \\
\hline & Efficiency & .037 & $3(149)$ & 1.934 & $\mathrm{~A}=.05, \quad \mathrm{~B}=-.04$ \\
\hline & Sociability & .152 & $3(149)$ & $8.872 * * * *$ & $\mathrm{~A}=-.05, \quad \mathrm{~B}=.27 * *$ \\
\hline & $\begin{array}{l}\text { Mental } \\
\text { health }\end{array}$ & .027 & $3(149)$ & 1.393 & $\mathrm{~A}=.16, \quad \mathrm{~B}=-.07$ \\
\hline & $\begin{array}{l}\text { Inter- } \\
\text { Relations }\end{array}$ & .111 & $3(149)$ & $6.192 * * *$ & $\mathrm{~A}=-.03, \quad \mathrm{~B}=.24 * *, \quad \mathrm{D}=.19 *$ \\
\hline \multirow[t]{5}{*}{$\begin{array}{l}\text { Group2. } \\
\text { C,EGI }\end{array}$} & Satisfaction & .054 & $4(148)$ & 2.12 & $\begin{array}{l}\mathrm{C}=.24, \quad \mathrm{E}=-.16, \quad \mathrm{G}=.06, \\
\mathrm{I}=-.15\end{array}$ \\
\hline & Efficiency & .041 & $4(148)$ & 1.569 & $\begin{array}{lll}\mathrm{C}=.17 & \mathrm{E}=-.25^{*} \quad \mathrm{G}=.21 \\
\mathrm{I}=-.05\end{array}$ \\
\hline & Sociability & .063 & $4(148)$ & $2.417 *$ & $\begin{array}{l}\mathrm{C}=.30^{* *} \mathrm{E}=-.06 \\
\mathrm{I}=.03\end{array}$ \\
\hline & $\begin{array}{l}\text { Mental } \\
\text { health }\end{array}$ & .025 & $4(148)$ & .943 & $\begin{array}{ll}\mathrm{C}=.10 & \mathrm{E}=-.05 \\
\mathrm{I}=-.16 & \end{array}$ \\
\hline & $\begin{array}{l}\text { Inter- } \\
\text { Relations }\end{array}$ & .093 & $4(148)$ & $3.798 * *$ & $\begin{array}{l}\mathrm{C}=.24^{* *} \quad \mathrm{E}=-.26^{*} \\
\mathrm{I}=-.18\end{array}$ \\
\hline \multirow[t]{5}{*}{$\begin{array}{l}\text { Group } 3 . \\
\text { FHJ }\end{array}$} & Satisfaction & .054 & $3(149)$ & $2.854 *$ & $\begin{array}{l}\mathrm{F}=.13 \\
\mathrm{H}=.13\end{array}$ \\
\hline & Efficiency & .139 & $3(149)$ & $\begin{array}{l}11.861 * * * \\
*\end{array}$ & $\begin{array}{l}\mathrm{F}=.41 * * * * \\
\mathrm{H}=-.01\end{array}$ \\
\hline & Sociability & .194 & $3(149)$ & $\begin{array}{l}11.926 * * * \\
*\end{array}$ & $\begin{array}{l}\mathrm{F}=.36 * * * * \\
\mathrm{H}=.11\end{array}$ \\
\hline & $\begin{array}{l}\text { Mental } \\
\text { health }\end{array}$ & .054 & $3(149)$ & $2.820 *$ & $\begin{array}{l}\mathrm{F}=.21 * \\
\mathrm{H}=.03\end{array}$ \\
\hline & $\begin{array}{l}\text { Inter } \\
\text { Relations }\end{array}$ & .296 & $3(149)$ & $\begin{array}{l}20.884 * * * \\
*\end{array}$ & $\begin{array}{ll}\mathrm{F}=.30^{* * *} & \mathrm{~J}=-.11 \\
\mathrm{H}=.30^{* * *} & \end{array}$ \\
\hline -control, & $\begin{array}{l}\text { B-protective } \\
\text { of privilege }\end{array}$ & & 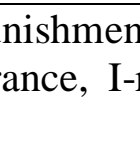 & D-cont & $\begin{array}{l}\text { iity, E-isolation, F-reward, G- } \\
\text { rmissiveness. } * \mathrm{P}<.05, * * \mathrm{P}<.01 \text {, }\end{array}$ \\
\hline
\end{tabular}

\section{DISCUSSIONS}

One cannot rule out the role of subjective home environment as perceived by adolescents in their psychological wellbeing. Significant association of HE variables with PW in correlation test reveals it (Table1). As expected, positive HE variables contributed more to the positive affect. The very high correlation of "nurture" and "reward" with the psychological well-being indicate the indispensability of an ambience imbued with positivity in order to ensure psychological wellbeing of adolescents. 
The three HE variables namely "control (A)", "conformity(B)", and "protectiveness(D)" which constitute disciplining atmosphere of the family showed highest F-changes in "sociability" $\left(\mathrm{R}^{2}\right.$ $=.15, \mathrm{~F}=8.872, \mathrm{P}<.000)$ and "interpersonal relations" $\left(\mathrm{R}^{2}=.11, \mathrm{~F}=6.19, \mathrm{P}<.001\right)$ as per regression analysis (table:4). Of these three HE variables, beta-loading for "protectiveness" $(\beta=.27, p<.01)$ was highest indicating its significant predictive power in "sociability" Also, the positive correlations of "control" with life satisfaction $(\mathrm{r}=.15, \mathrm{p}<.05)$, sociability $(\mathrm{r}=.14, \mathrm{P}<.05)$ and mental health $(\mathrm{r}=.15, \mathrm{p}<.05)$, were moderate and significant. In the correlations of "protectiveness" with satisfaction $(\mathrm{r}=.25, \mathrm{p}<.001)$ and sociability $(\mathrm{r}=.32, \mathrm{p}<.000)$ later was more prominent. Also, "conformity" revealed positive association with sociability $(\mathrm{r}=.31, \mathrm{P}<.000)$, interpersonal relations $(\mathrm{r}=.13, \mathrm{p}<.05)$ and efficiency $(\mathrm{r}=.19, \mathrm{p}<.01)$ of which association with sociability was most significant. That is, these disciplinary variables mainly affected the social life of adolescents affirmatively and contributed to the enhancement of well-being in general. An atmosphere dominant in conformity and control might be providing adolescents with a more concrete frame of reference for choosing more realistic standards for behaving especially in collective settings. This might enable them to cope fairly with the situational demands which may in turn help in the betterment of sociability and interpersonal relations. Anyway the observed result, endorses the view that parental monitoring has always been associated with better adolescent adjustment (Lamborn et al. 1996, Pettit et al.2001). From a macro level, overall result seems to reflect the "collective" culture extant in Indian family system in which conformity to the values and standards of elders and caretakers is supported and reinforced and there is minimum space to exercise individuality, compared to western "individualistic" cultures. Finally, it agrees with the conclusions from the previous studies that well-being may be gained or sacrificed by incorporating the self into collectives (Bettencourt \&Dorr, 1997; Crocker, Luhtanen, Blaine, \&Broadnax, 1994; Suh, Oishi, Diener, \& Triandis, 1998).

More pronounced negative disciplining practices such as punishment(C), rejection(I), social isolation(E) and deprivation of privileges which contribute to adverse, perhaps pathological ambience in HE affects mainly interpersonal relationship of adolescents. Of these variables, "Isolation"(E) (r=-18,P,.01) "rejection" (I) $(\mathrm{r}=-.21, \mathrm{P}<.01)$ and deprivation of privileges $(\mathrm{r}=-.13$, $\mathrm{p}<.05)$ showed significant negative correlation with interpersonal relationship only(table:1). The other aspects of PW were not affected by them. As in the case of conformity and control, disciplining via "punishment" (negative reinforcement) had significant positive correlation with life satisfaction $(\mathrm{r}=.14, \mathrm{P}<.05)$ and sociability $(\mathrm{r}=.21, \mathrm{p}<.01)$. F-change in the multiple regression analysis for these negative $\mathrm{HE}$ variables were significant in interpersonal relations $\left(\mathrm{R}^{2}=\right.$ $.093, \mathrm{~F}=3.796, \mathrm{p}<.01)$ and the same was only moderately significant in "sociability" level $\left(\mathrm{R}^{2}\right.$ $=.06, \mathrm{~F}=2.42, \mathrm{P}, .05)$. "Isolation" of the negative $\mathrm{HE}$ had maximum loading in interpersonal relations $(\beta=-.26, \mathrm{p}<.05)$ and the same in sociability was not significant(table:4). This shows that negative $\mathrm{HE}$ variables may adversely affect the ability to form secure and trusting relationship with others, which will verily hamper the well-being of individual in the long run. Also, establishing good interpersonal relationship with others is a one of the major developmental 
tasks of adolescents. A negative HE usually hurts the need for "autonomy" and self-esteem which may perturb the proper dynamism behind the formation of good interpersonal relationships as it hinders the satisfaction of basic psychological needs "autonomy, competency and intimacy" as per self determination theory. External punishments lower autonomy on the self-determination continuum, the child becomes less self-determined. (Deci\& al., 2001; Deci, Koestner\& Ryan, 1999; Deci, Eghrari, Patrick\& Leone, 1994). The environment in satisfaction of basic psychological needs is believed to lead to psychological well-being (Ryan \& al., 1995).

The way in which an environment teeming with positivity improves the psychological well-being is indisputable. A "rewarding" environment has highly significant positive correlation with almost all components of PW (Table:1). In the correlations of "reward", that with efficiency $(\mathrm{r}=.41, \mathrm{p}<.000)$ and interpersonal relations $(\mathrm{r}=.49, \mathrm{P}<.000)$ were the highest. Role of reward in "efficiency" is very much important from the academic point of view as "efficiency" in adolescent period is tantamount to efficiency mainly in academic life. This can be explained in terms of following observations from past studies that academic achievement was found to be having significant relationship with self-concept (Saraswat 1982; Desai and Uchat 1983; Panwar1986; Lyon1993; Kobal and Musek 2001; Trautwein et al. 2006 and Tracy 2007). Selfconcept is a mediating variable between home environment and academic achievement Hattie (1984) and home environment was found to be influencing the self concept in one way or the other (Revicki 1981; Lau 1995; Massey 1999; Lau and Kwok 2000 and Foluke-Henderson 2007). A rewarding atmosphere is likely to contribute to the formation of a healthy, realistic selfconcept which may eventually get reflected in the "efficiency" level of adolescents. "Permissiveness", another positive HE variable exhibited a pronounced role solely in the "efficiency" component of PW (r=.18,p<.01) (table:1)."Nurture" also exhibited significant correlation with almost all components of PW. And the correlation with interpersonal relation was highest. F-change for the positive $\mathrm{HE}$ variables was greatest and highly significant in inter personal relations $\left(\mathrm{R}^{2}=.296, \mathrm{~F}=20.884, \mathrm{P}<.000\right)$ (table:4) and beta-loadings for "nurture" $(\beta=.30$, $\mathrm{P}<.001)$ and "reward" $(\beta=.30, \mathrm{P}<.001)$ in it was equally high and significant. The significant role of positive HE in every aspect of PW indicates that a family deprived of these positive qualities might be a family knowingly or unknowingly fostering the seeds of psychopathology. The observation that only positive HE variables "reward" and "nurture" had any significant role in the "mental health"(table:1,see figure) of the selected sample corroborates this conclusion.

\section{CONCLUSION \& IMPLICATIONS}

The above result reveals the best criterion variables for determining the kind of environment truly necessary for adolescent psychological well-being. The study asserts that psychological well-being of adolescents is solely a function of subjective environment of home of which he/she is a part. And the positivity in the ambience of home is the main factor that contributes to their psychological well-being. At the same time, disciplining through control, conformity etc.,not 
always threaten the psychological well-being rather enhances it provided, there isn't any extreme form of punishments like social isolation and rejection.

Although addressing adolescent's problems in terms of psychological distress is important, fostering increased attention to their psychological well-being has its own benefits in the realm of mental health researches. On the practical side the emergence of a new psychotherapeutic technique called Positive Psychotherapy (Nossart, 1968) is very much promising. But all these attempts should give enough space to explore the environment especially the home environment of adolescents and identify lurking impediments in it for the accomplishment of their psychological well-being.

\section{REFERENCE}

1. Bandura, A. (1986). Social foundations of thought and action. Englewood Cliffs, NJ: Prentice Hall.

2. Bandura, A. (1997). Self-efficacy: The exercise of control. New York: Freeman.

3. Baumeister, R. F., \& Leary, M. R. (1995). The need to belong: Desire for interpersonal attachments as a fundamental human motivation. Psychological Bulletin, 117, 497-529.

4. Bettencourt, B. A., \& Dorr, N. (1997). Collective self-esteem as a mediator of the relationship between all centrism and subjective well- being. Personality and Social Psychology Bulletin, 23, 963-972.

5. Bowlby, J. (1988). A secure base: Clinical applications of attachment theory. London: Tavistock.

6. Brewer,M. (1991). The social self: On being the same and different at the same time. Personality and Social Psychology Bulletin, 17, 475-482.

7. Brewer, M. (1993a). The role of distinctiveness in social identity and group behavior. In M. Hogg \& D. Abrams (Eds.), Group motivation: Social psychological perspectives (pp. 1-16).London: Harvester Wheat sheaf.

8. Brewer,M. (1993b). Social identity, distinctiveness, and in-group homogeneity. Social Cognition, 11, 150-164

9. Bronfenbrenner, U., \& Morris, P.A. (1998). The ecology of developmental process. In Handbook of Child Psychology, Theoretical Models of Human Development, ed. W Damon, RM Lerner, 1:993-1028. New York: Wiley. $5^{\text {th }}$ ed.

10. Crocker, K., Luhtanen, R., Blaine, B., \& Broadnax, S. (1994). Collective self-esteem and psychological well-being among White, Black, and Asian college students. Personality and Social Psychology Bulletin, 20, 503-513.

11. Cheek, J. M., \& Buss, A. H. (1981).Shyness and sociability. Journal of Personality and Social Psychology, 41, 330-339Deci, E. L., \& Ryan, R. M. (1985). Intrinsic motivation and self-determination in human behavior. New York: Plenum.

12. Deci, E. L., \&Ryan, R. M. (1991). Amotivational approach to self: Integration in personality. In R. Dienstbier (Ed.), Nebraska symposium on motivation: Vol. 38, Perspectives on motivation (pp. 237-288). Lincoln, NE: University of Nebraska Press. 
13. Devi Sarada, M., \& KavithaKiran, ( 2002). Family factors associated with scholastic backwardness of secondary school children. Journal of Community Guidance and Research, 19(2): 167-172.

14. Diener, E., Lucas, R., Schimmack, U., \& Helliwell, J. (2009). Well-being for public policy Oxford: Oxford

15. Eccles, J. \& Wigfield, A. (2002).Self-regulation beliefs, values, and goals. Annual Review of Psychology, 53, 109-132.

16. Fisher, S. (1994). Stress in academic life. Buckingham: The Society for Research into Higher Education and Open University Press. University Press.

17. Freidli, L. (2009). Mental health, resilience and inequalities. Copenhagen: World Health Organization Europe.

18. Hair, E., Moore, K., Garrett, S., Kinukawa, A., Lippman, L. \& Michelson, E. (2005).The parent adolescent relationship scale. In K. Moore \& L. Lippman (Eds.) What do children need to flourish (pp. 183-202). New York: Springer Science.

19. Jessica, A., \& Savage. (2011). Increasing Adolescents' Subjective Well-Being: Effects of Positive Psychology Intervention in Comparison to the Effects of Therapeutic Alliance, Youth Factors, and Expectancy for Change, Graduate school thesis, University of South Florida

20. Kerns, K. A., Klepac, L. \& Cole, A. (1996). Peer relationships and preadolescents' perceptions of security in the child-mother relationship. Developmental Psychology, 32, 457-466.

21. Lamborn, S., Dornbusch, S., \& Steinberg, L. (1996). Ethnicity and community context as moderators of the relation between family decision making and adolescent adjustment. Child Dev. 66:283-301

22. Lewnt . R W. (2003) Toward a unifying theoretical and practical perspective on wellbeing and psychological adjustment. Journal of counseling psychology, 51(4), 482509

23. Minuchin, P. (2002). Looking toward the horizon: present and future in the study of family systems. In Retrospect and Prospect in the Psychological Study of Families, ed. S McHale, W Grolnick. Mahwah, NJ: Erlbaum Parker, J., \& Benson, M. (2004).

24. Parker, J.S., \& Benson, M. J. (2004) Parent-adolescent relations and adolescent functioning: Self- esteem, substance abuse, and delinquency. Adolescence, 39(155): 519-530.

25. Pavot, W., \& Diener, E. (1993). Review of the Satisfaction with Life Scale. Psychological Assessment, 5, 164-172.

26. Reeve, J. (2002). Self-Determination Theory Applied to Educational Settings. In Deci, E. \& Ryan, M. (Eds.), Handbook of Self-Determination. Rochester, NY: The University of Rochester Press.

27. Resnick, M., Ireland, M. \&Borowsky, I. (2004). Youth violence perpetration: What protects? What predicts? Findings from the National Longitudinal Study of Adolescent Health. Journal of AdolescentHealth, 35(5): 424e1-424e10.

28. Ryan, R. \& Deci, E. (2000).Self-Determination Theory and the Facilitation of Intrinsic motivation, Social Development, and Well-Being. American Psychologist, January, $55(1), 68-78$. 
29. Ryan, R., Deci, E. \&Grolnick, W. (1995). Autonomy, Relatedness, and the Self: Their Relation to Development and Psychopathology. In Cicchetti, D. \& Cohen, D. (Eds.), Developmental Psychopathology, Volume 1, Theory and Methods. NewＹｏrk: John Wiley et Sons. Inc.

30. Ryan, R. M. (1995). Psychological needs and the facilitation of integrative processes. Journal of Personality, 63, 397-427.

31. Suldo, S.M., \& Huebner, E.S. ( 2006). Is extremely high life satisfaction during adolescence advantageous? Social Indicators Research, 78: 179-203

32. Suh, E., Diener, E., Oishi, S., \&Triandis, H. C. 1998. The shifting basis of life satisfaction judgments across cultures: Emotion vs. norms. Journal of Personality \& Social Psychology, 74, 482-493.

33. Sine L (1998). A path model of couple intimacy: Examining the residuals of parenting style on young adult children's heterosexual couples relationships" Child and Family Studies -

34. Steinberg Laurence, Lamborn SD, Dornbusch SM, Darling Nancy 1992. Impact of parenting practices on adolescent achievement: authoritative parenting,

35. Turner, J. C., Hogg, M., Oakes, P., Reicher, S., \&Wetherell, M. (1987).Rediscovering the social group: A self-categorization perspective. Oxford: Blackwell.

36. Wiest, D., Wong, E. \& Kreil, D. (1998).Predictors of global self-worth and academic performance among regular education, learning disabled, and continuation high school students. Adolescence, 33(131) 601-618. 